\title{
Mycotoxin Profile and Phylogeny of Pathogenic Alternaria Species Isolated from Symptomatic Tomato Plants in Lebanon
}

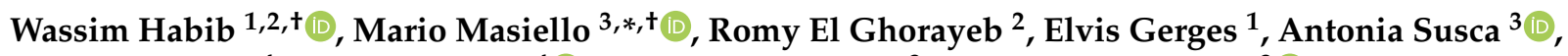 \\ Giuseppe Meca ${ }^{4}$, Juan M. Quiles ${ }^{4}{ }^{(\mathbb{C}}$, Antonio F. Logrieco ${ }^{3}$ and Antonio Moretti ${ }^{3}{ }^{(\mathbb{B}}$ \\ 1 Laboratory of Mycology, Department of Plant Protection, Lebanese Agricultural Research Institute, \\ P.O. Box 90-1965, Fanar 1202, Lebanon; whabib@lari.gov.lb (W.H.); egerges11@gmail.com (E.G.) \\ 2 Department of Nutrition and Food Sciences, Faculty of Arts and Sciences, Holy Spirit University of Kaslik, \\ P.O. Box 446, Jounieh 1200, Lebanon; romyghorayeb@gmail.com \\ 3 Institute of Science of Food Production-ISPA, Research National Council—CNR, Via Amendola, 122/O, \\ 70126 Bari, Italy; antonella.susca@ispa.cnr.it (A.S.); antonio.logrieco@ispa.cnr.it (A.F.L.); \\ Antonio.moretti@ispa.cnr.it (A.M.) \\ 4 Department of Preventive Medicine, Nutrition and Food Science Area, University of Valencia, Avenida Vicent \\ Andres Estelles s/n, 46100 Valencia, Spain; Giuseppe.Meca@uv.es (G.M.); Juan.Quiles@uv.es (J.M.Q.) \\ * Correspondence: mario.masiello@ispa.cnr.it \\ + These authors contributed equally to this work.
}

check for updates

Citation: Habib, W.; Masiello, M.; El Ghorayeb, R.; Gerges, E.; Susca, A.; Meca, G.; Quiles, J.M.; Logrieco, A.F.; Moretti, A. Mycotoxin Profile and Phylogeny of Pathogenic Alternaria Species Isolated from Symptomatic Tomato Plants in Lebanon. Toxins 2021, 13, 513. https://doi.org/ $10.3390 /$ toxins 13080513

Received: 1 July 2021

Accepted: 20 July 2021

Published: 22 July 2021

Publisher's Note: MDPI stays neutral with regard to jurisdictional claims in published maps and institutional affiliations.

Copyright: (c) 2021 by the authors. Licensee MDPI, Basel, Switzerland. This article is an open access article distributed under the terms and conditions of the Creative Commons Attribution (CC BY) license (https:/ / creativecommons.org/licenses/by/ $4.0 /)$.

\begin{abstract}
The tomato is one of the most consumed agri-food products in Lebanon. Several fungal pathogens, including Alternaria species, can infect tomato plants during the whole growing cycle. Alternaria infections cause severe production and economic losses in field and during storage. In addition, Alternaria species represent a serious toxicological risk since they are able to produce a wide range of mycotoxins, associated with different toxic activities on human and animal health. Several Alternaria species were detected on tomatoes, among which the most important are A. solani, A. alternata, and A. arborescens. A set of 49 Alternaria strains isolated from leaves and stems of diseased tomato plants were characterised by using a polyphasic approach. All strains were included in the recently defined phylogenetic Alternaria section and grouped in three well-separated sub-clades, namely A. alternata (24 out of 49), A. arborescens (12 out of 49), and A. mali morpho-species (12 out of 49). One strain showed high genetic similarity with an $A$. limoniasperae reference strain. Chemical analyses showed that most of the Alternaria strains, cultured on rice, were able to produce alternariol $(\mathrm{AOH})$, alternariol methyl ether (AME), altenuene (ALT) and tenuazonic acid (TA), with values up to $5634,16,006,5156$, and $4507 \mathrm{mg} \mathrm{kg}^{-1}$, respectively. In addition, $66 \%$ of the strains were able to co-produce simultaneously the four mycotoxins investigated. The pathogenicity test carried out on 10 Alternaria strains, representative of phylogenetic sub-clades, revealed that they were all pathogenic on tomato fruits. No significant difference among strains was observed, although A. alternata and A. arborescens strains were slightly more aggressive than $A$. mali morpho-species strains. This paper reports new insights on mycotoxin profiles, genetic variability, and pathogenicity of Alternaria species on tomatoes.
\end{abstract}

Keywords: multilocus gene sequencing; toxigenic fungi; Alternaria alternata; Alternaria arborescens; Alternaria mali morpho-species

Key Contribution: We studied a set of Alternaria strains isolated from tomato plants in Lebanon. The polyphasic approach used in this study showed that all strains belonged to the recently defined Alternaria section and that $A$. solani species was not detected in all samples. Pathogenicity tests and mycotoxin analyses revealed that Alternaria contamination represents both a phytopathological issue and a potential toxicological risk for human consumption. The capability of Alternaria strains to produce mycotoxins in field conditions and the capability of mycotoxins to translocate from leaves or stems to tomato fruits needs to be further investigated. 


\section{Introduction}

The tomato is one of the most important agricultural crops produced and consumed in Lebanon. Grown on about 3800 hectares, in open fields or in greenhouses, after potato the tomato is considered the second biggest agro-food crop in terms of production and consumption, with a volume of about 300,000 tons [1]. Almost all tomato production is consumed in Lebanon, and about 5000 tons per year are exported to the Arab gulf countries.

The tomato is highly susceptible to several fungal pathogens, especially necrotrophic agents such as Alternaria species [2,3], which are the causal agents of early blight, a destructive disease that compromises the yield [4].

Alternaria is a ubiquitous fungal genus that includes endophytic, saprophytic and pathogenic species commonly found in soil, air, food commodities, and on decaying plant tissues [5]. As plant pathogens, Alternaria species have been reported on important crops, including cereals, oil crops, ornamentals, vegetables and fruits $[5,6]$. Alternaria survives as mycelium or conidia on decaying plant debris for a long time, or as a latent infection in seeds [7]. Moreover, weakened or wounded tissues are more prone to being colonised by Alternaria species [7,8].

Several Alternaria species have been reported on tomato plants and fruits. In particular, $A$. solani is considered the most important pathogen associated with early blight disease of tomato and potato plants $[9,10]$, whereas $A$. arborescens and A. alternata are considered to be the most important species associated with stem canker and black spots of tomato fruits [11-13]. Moreover, other Alternaria species have been reported to be isolated from symptomatic tomato plants or fruits, such as $A$. brassicicola, A. tenuissima, A. consortialis, A. linariae, and $A$. grandis [14-16]. Nevertheless, the pathogenic impact of $A$. alternata on tomatoes is controversially discussed, since some researchers considered both $A$. solani and A. alternata as causal agents of early blight disease [9], whereas others reported that A. alternata is only a secondary invader $[10,17]$.

Based primarily on morphological characters, Simmons organised the genus complexity of Alternaria by launching a species-group concept, and identified more than 270 Alternaria morpho-species [18,19]. Recently, severe taxonomic studies, based on the analyses of informative genes, including the major allergen alt-a1 (alt-a1), glyceraldehyde-3phosphate dehydrogenase ( $g p d)$, translation elongation factor (tef), and calmodulin allowed the redefinition of Alternaria species into 27 phylogenetic sections [20,21]. All small-spored Alternaria species, such as $A$. alternata, $A$. arborescens, and A. tenuissima, were grouped together in the Alternaria section, in addition to several other species, all synonymised with $A$. alternata species, considered as type species [22]. Conversely, the large-spored $A$. solani was included in section Porri [22-26], while recently a new section, named Omanenses, has been proposed [27]. The importance of well-defined species boundaries in this genus is also related to the high capability of several Alternaria species to produce mycotoxins and define a species-specific risk profile [5-28].

Indeed, the occurrence of Alternaria species on tomatoes is often associated with the production of mycotoxins in the fruit, which can be dangerous to human health [29-31]. Several studies reported that the accumulation of these mycotoxins in agri-food products is influenced by several environmental conditions that affect both the pre-harvest mould development and the consequent mycotoxin production [32,33]. Alternaria species produce several toxic metabolites, such as alternariol $(\mathrm{AOH})$, alternariol methyl ether (AME), altertoxin-I (AT-I), altertoxin-II (AT-II) and tenuazonic acid (TA) [5,13,29,34-37]. Wang et al. [34] reported AAL-toxin produced by A. arborescens [11] as phytotoxic compounds responsible for the apoptosis of tomato cells by inhibiting ceramide biosynthesis [38]. Studies have shown that TA was responsible for some changes in the oesophageal mucosa of mice [39], and was reported as a cytotoxic, phytotoxic, antitumoral, antiviral, antibiotic and antibacterial compound [40]. Furthermore, AT-I was identified as toxic in mice and mutagenic to mammalian cell lines [41], and $\mathrm{AOH}$ and AME were identified as genotoxic and mutagenic, with immune modulating effects [42]. In addition, more recently, Huybrechts et al. [43] associated Alternaria mycotoxins to colon rectal cancer in humans. 
Despite the widespread occurrence of early blight on tomatoes in Lebanon, no data are currently available on the population of Alternaria species occurring on tomatoes. Therefore, in order to evaluate the Alternaria mycotoxin risk and achieve knowledge for improving the disease management strategy and increasing the quality of the production, this work aimed to: (a) identify the main Alternaria species causing early blight of tomatoes in Lebanon and establish their phylogenetic relationships by using a multilocus sequence approach; (b) define their mycotoxin profiles; (c) assess their pathogenicity on the tomato fruits.

\section{Results}

\subsection{Phylogenetic Analysis}

The sequences of each gene were aligned and cut at the ends to analyse a common fragment for all of the strains. In particular, for the alt-a1 gene a fragment of about 440 nucleotides (nt) was considered; for the gpd gene a fragment of $510 \mathrm{nt}$, for the calmodulin gene a fragment of $750 \mathrm{nt}$, and for the $\beta$-tubulin gene a fragment of $500 \mathrm{nt}$. All genes were very informative for discriminating between Alternaria species, although alt-a1 and calmodulin genes showed the highest degree of variability.

The final sequence alignment of the combined dataset comprising 67 taxa included 49 Alternaria strains isolated from tomatoes, 17 Alternaria reference sequences and one strain of Stemphylium isolated also from tomatoes (Altern1357) as the outgroup taxon (Figure 1). The phylogenetic analysis of the concatenated sequences of the four fragments (alt-a1, gpd, calmodulin and $\beta$-tubulin genes) resulted in a phylogenetic tree that allowed us to discriminate between three well-separated clades, supported by high bootstrap values (>90), corresponding to Section Alternaria, Section Porri and Section Brassicicola.

All field strains grouped with the Alternaria reference sequences of the species belonged to the Alternaria section (Figure 1). In detail, 25 strains (sub-clade A1) grouped with A. alternata, A. turkisafria, and A. tenuissima species, showed a high homology with references and among themselves (Figure 1). The Alternaria strain Altern1350 clustered with the A. limoniasperae reference sequence (Figure 1 ). In the Alternaria section, a sub-clade (sub-clade A2) of 12 field strains clustered with the A. arborescens reference strain. In particular, three strains (Altern1364, Altern1368, and Altern1359) were very close to the reference (Figure 1). In this sub-group, a high variability was observed. In particular, the strains Altern1354, Altern1355 and Altern1358, were similar among them, and further away from $A$. arborescens reference strains, due to an insertion of $8 \mathrm{nt}$ in the Calmodulin fragment. In the sub-clade A3, including A. longipes, A. tangelonis, A. citriarbusti, A. mali reference strains, one strain (Altern1367) was very close to $A$. citriarbusti; 11 strains, showing high homology among them, were closely related to both $A$. mali and $A$. citriarbusti references but did not cluster with any reference strain.

\subsection{Mycotoxin Production}

Thirty-five Alternaria strains were selected as representative of the three phylogenetic sub-clades (Figure 1) to evaluate their capacity to produce AME, AOH, ALT, and TA. The mycotoxin production of each strain and the mean values of each Alternaria phylogenetic sub-clade are reported in Table 1 . The majority of the strains tested produced $\mathrm{AOH}(94.3 \%)$, AME (94.3\%), and ALT (91.4\%), whereas TA was produced by $68.6 \%$ of the strains tested. In addition, as a reason of particular concern, $65.7 \%$ of the strains were able to co-produce simultaneously the four mycotoxins investigated. 


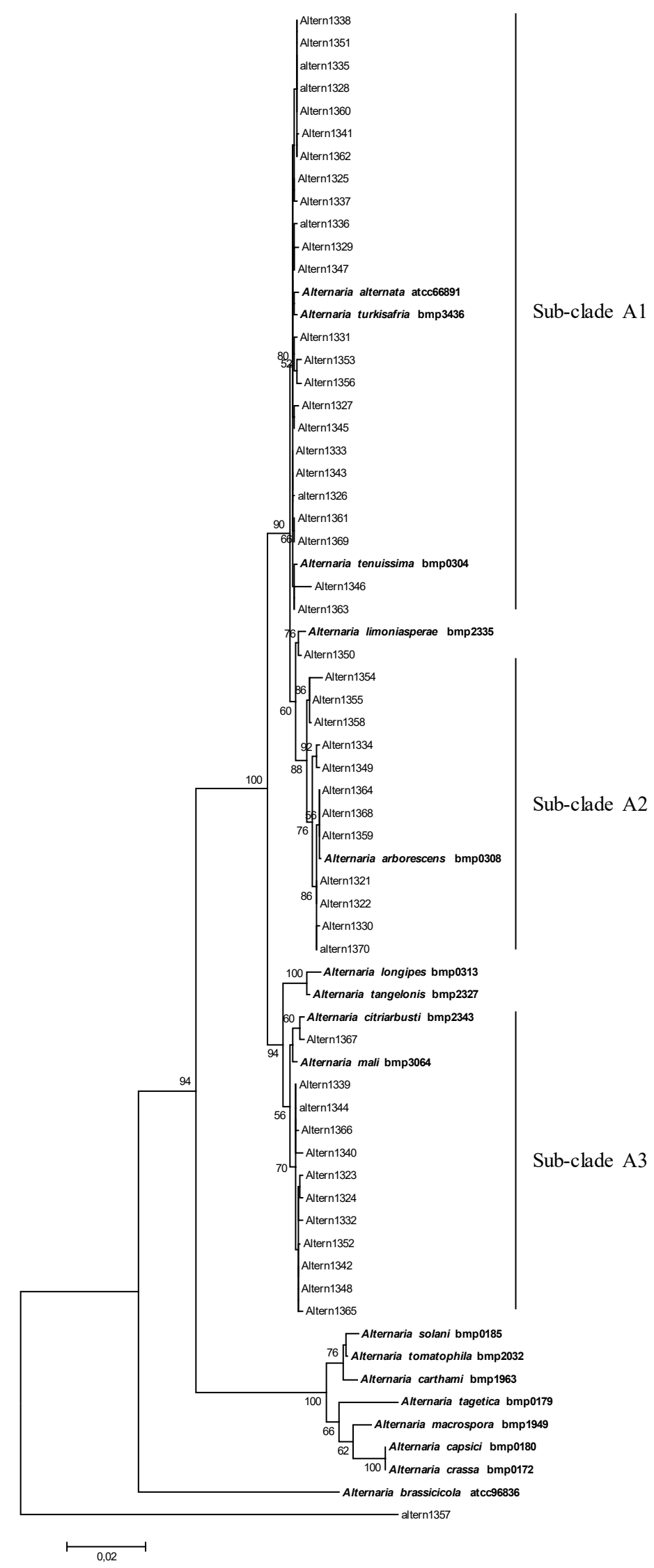

Figure 1. Phylogenetic tree generated and obtained by maximum likelihood method (bootstrap 1000 replicates) of combined alt-a1, gpd, cal and tub gene sequences of 50 fungal strains isolated from infected tomato plants. 
Table 1. Production of alternariol (AOH), alternariol methyl ether (AME), altenuene (ALT), and tenuazonic acid (TA), expressed in $\left(\mathrm{mg} \mathrm{kg}^{-1}\right)$, evaluated on 35 strains of Alternaria species from tomato leaves and stems affected by early blight.

\begin{tabular}{|c|c|c|c|c|c|}
\hline \multirow{2}{*}{ Strain } & \multirow{2}{*}{ Alternaria Species } & \multicolumn{4}{|c|}{ Mycotoxin (mg $\left.\cdot \mathrm{kg}^{-1}\right)$} \\
\hline & & $\mathrm{AOH}$ & AME & ALT & TA \\
\hline Altern1325 & A. alternata & 26 & 20 & 1 & 4442 \\
\hline Altern $1327 *$ & A. alternata & 908 & 6900 & 1538 & 2658 \\
\hline Altern1328 & A. alternata & 4567 & 4967 & 1025 & $\mathrm{Nd}^{* *}$ \\
\hline Altern1329* & A. alternata & 1271 & 4967 & 558 & $\mathrm{Nd}$ \\
\hline Altern1331 & A. alternata & 102 & 516 & 462 & 603 \\
\hline Altern1333 & A. alternata & 84 & 82 & 1959 & 1331 \\
\hline Altern1336 & A. alternata & 126 & 855 & 74 & 532 \\
\hline Altern1337 & A. alternata & 676 & 632 & 4097 & $\mathrm{Nd}$ \\
\hline Altern1341 * & A. alternata & 4002 & 9172 & 214 & 3938 \\
\hline Altern $1343 *$ & A. alternata & 131 & 660 & 2687 & $\mathrm{Nd}$ \\
\hline Altern1345 & A. alternata & 1646 & 11,021 & 394 & $\mathrm{Nd}$ \\
\hline Altern1351 & A. alternata & 3090 & 8678 & 1114 & 145 \\
\hline Altern1353 & A. alternata & 441 & 2718 & 1238 & 2066 \\
\hline Altern1360 & A. alternata & $\mathrm{Nd}$ & $\mathrm{Nd}$ & $\mathrm{Nd}$ & 2035 \\
\hline Altern1362 & A. alternata & 3062 & 15,070 & 5156 & 1155 \\
\hline Altern1346 & A. alternata & 1199 & 2385 & 1950 & $\mathrm{Nd}$ \\
\hline \multicolumn{2}{|c|}{ Mean value } & 1422 & 4576 & 1498 & 1890 \\
\hline \multicolumn{2}{|c|}{ Min } & 26 & 20 & 1 & 145 \\
\hline \multicolumn{2}{|c|}{ Max } & 4567 & 15,070 & 5156 & 4442 \\
\hline Altern1350 & A. limoniasperae & $\mathrm{Nd}$ & 102.51 & 3.86 & $\mathrm{Nd}$ \\
\hline Altern1321 & A. arborescens & 27 & 25 & 42 & 2083 \\
\hline Altern1322 & A. arborescens & 333 & 249 & 134 & 283 \\
\hline Altern 1330 * & A. arborescens & 2059 & 6395 & 570 & $\mathrm{Nd}$ \\
\hline Altern1334 & A. arborescens & 610 & 405 & 387 & 2713 \\
\hline Altern1349 & A. arborescens & 5634 & 16,006 & 735 & 1251 \\
\hline Altern1354 & A. arborescens & 3501 & $\mathrm{Nd}$ & $\mathrm{Nd}$ & $\mathrm{Nd}$ \\
\hline Altern1355* & A. arborescens & 4612 & 5737 & 597 & 1008 \\
\hline Altern $1358 *$ & A. arborescens & 264 & 142 & 28 & 456 \\
\hline Altern1359 & A. arborescens & 1786 & 3026 & 550 & 754 \\
\hline Altern1364 & A. arborescens & 3271 & 6662 & 1560 & 496 \\
\hline Altern1368 & A. arborescens & 69 & 860 & 328 & 75 \\
\hline Altern1370 & A. arborescens & 2731 & 12,868 & 894 & 3777 \\
\hline \multicolumn{2}{|c|}{ Mean value } & 2075 & 4761 & 529 & 1290 \\
\hline \multicolumn{2}{|c|}{ Min } & 27 & 25 & 28 & 75 \\
\hline \multicolumn{2}{|c|}{ Max } & 5634 & 16,006 & 1560 & 3777 \\
\hline Altern1323 * & A. mali & 92 & 23 & 286 & 4507 \\
\hline Altern1332 & A. mali & 254 & 10,182 & 1153 & 649 \\
\hline Altern 1340 * & A. mali & 384 & 893 & 2046 & 1896 \\
\hline Altern1342 & A. mali & 2367 & 10,998 & 2722 & $\mathrm{Nd}$ \\
\hline Altern1344 & A. mali & 796 & 6593 & $\mathrm{Nd}$ & $\mathrm{Nd}$ \\
\hline Altern1352 * & A. mali & 915 & 7111 & 1326 & 452 \\
\hline \multicolumn{2}{|c|}{ Mean value } & 802 & 5967 & 1507 & 1876 \\
\hline \multicolumn{2}{|c|}{ Min } & 92 & 23 & 286 & 452 \\
\hline \multicolumn{2}{|c|}{ Max } & 2367 & 10,998 & 2722 & 4507 \\
\hline
\end{tabular}

*: Alternaria strains used in pathogenicity test; **: Nd: Not detected.

In the $A$. alternata group (sub-clade A1), with the exception of the Alternaria strain Altern1360, that produced only TA $\left(2035 \mathrm{mg} \mathrm{kg}^{-1}\right)$, all strains were able to produce simultaneously AOH, AME, and ALT with mean values of 1422,4576 , and $1498 \mathrm{mg} \mathrm{kg}^{-1}$, respectively. However, the mycotoxin quantities produced were dramatically variable for all mycotoxins, ranging between 26 and 4567, 20 and 15,070, and 1 and $5156 \mathrm{mg} \mathrm{kg}^{-1}$, for $\mathrm{AOH}, \mathrm{AME}$, and ALT, respectively (Table 1). These data showed a high intraspecific variability within this group. Tenuazonic acid was produced by 10 out of 16 strains included in this group, with values very variable, ranging between 145 and $4442 \mathrm{mg} \mathrm{kg}^{-1}$, 
with a mean value of $1890 \mathrm{mg} \mathrm{kg}^{-1}$. The strain Altern1350, showing a high phylogenetic homology with the A. limoniasperae bmp2335 strain, produced a low quantity of AME $\left(102 \mathrm{mg} \mathrm{kg}^{-1}\right)$ and ALT $\left(4 \mathrm{mg} \mathrm{kg}^{-1}\right)$.

All of the strains belonging to sub-clade A2, assigned to A. arborescens species-group, with the exception of Altern 1354 that produced only $\mathrm{AOH}\left(3501 \mathrm{mg} \mathrm{kg}^{-1}\right)$, were able to produce the mycotoxins analysed. As observed in sub-clade A1, the quantity of mycotoxins was very variable, ranging between 27 and $5634 \mathrm{mg} \mathrm{kg}^{-1}$ (mean value 2075) for $\mathrm{AOH}$, between 25 and 16,006 mg kg${ }^{-1}$ (mean value 4761) for AME, between 28 and $1560 \mathrm{mg} \mathrm{kg}^{-1}$ (mean value 529) for ALT, and between 75 and $3777 \mathrm{mg} \mathrm{kg}^{-1}$ (mean value 1290) for TA.

With regard to Alternaria strains included in the sub-clade A3, all strains were able to produce $\mathrm{AOH}$ and $\mathrm{AME}$, with values ranging between 92 and $2367 \mathrm{mg} \mathrm{kg}^{-1}$ (mean value 802) and between 23 and 10,998 $\mathrm{mg} \mathrm{kg}^{-1}$ (mean value 5967), respectively. For ALT and TA production, only one out of six strains (Altern1344) and two out of six (Altern1342, Altern1344), were not producers.

Among the four mycotoxins, AME was the highest mycotoxin produced in all phylogenetic groups, with values up to $16,006 \mathrm{mg} \mathrm{kg}^{-1}$ (A. arborescens Altern1349 strain) and ranging from 20 to $16,006 \mathrm{mg} \mathrm{kg}^{-1}$. Tenuazonic acid was the least mycotoxin produced, since $37 \%$ of $A$. alternata strains, $16 \%$ of $A$. arborescens strains, and $33 \%$ of $A$. mali morpho-species strains did not produce it (Table 1).

\subsection{Pathogenicity Test}

The pathogenicity test on Grappe Randala tomato cultivar revealed that Alternaria representative strains of each sub-clade are all pathogenic on tomato fruits (Figure 2). During the first week of evaluation, the lesions caused by the Alternaria strains phylogenetically grouped in A. mali sub-clade (sub-clade A3) were slightly larger than lesions caused by Alternaria strains grouped in A. alternata and A. arborescens sub-clades (Figure 2). However, after 14 days, $A$. alternata and $A$. arborescens species produced larger lesions $(34.3 \mathrm{~mm}$ and $34.7 \mathrm{~mm}$, respectively) than the $A$. mali morpho-species ( $30.7 \mathrm{~mm}$ ). Nevertheless, no significant difference between the strains of each sub-clade was observed.

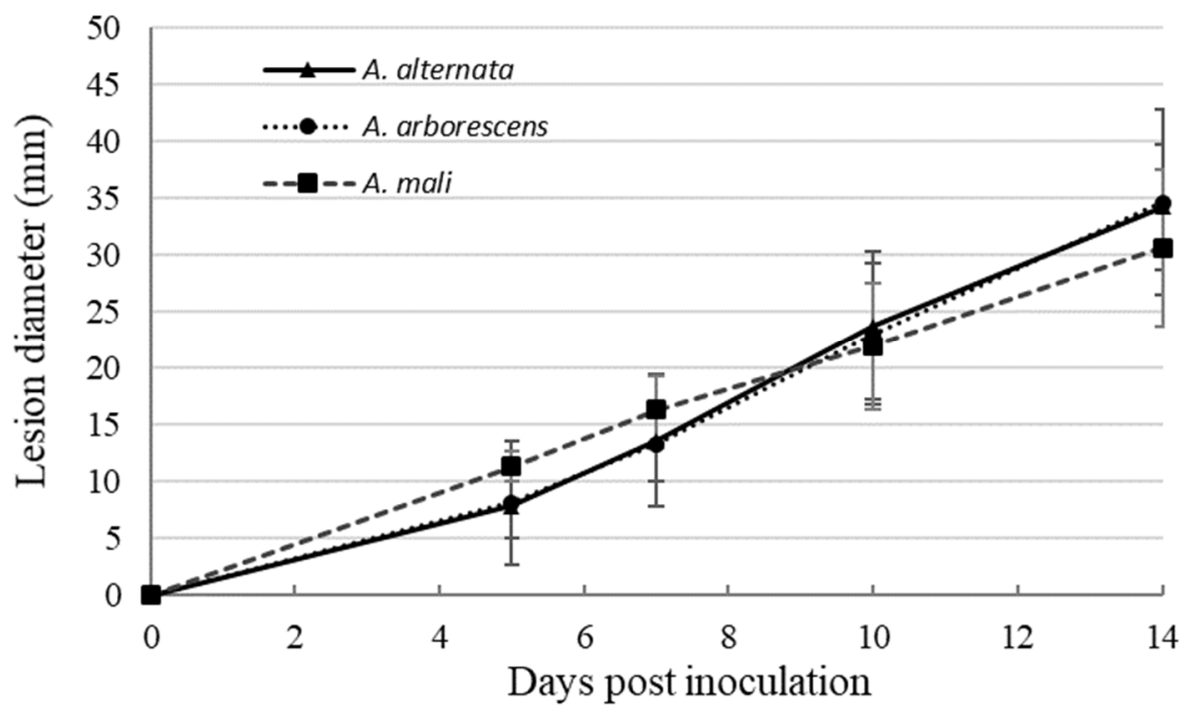

Figure 2. Mean values of the progression of the lesions caused on tomato fruits by a set of 10 Alternaria strains included in A. alternata (4 strains), A. arborescens (3 strains), and A. mali morpho-species (3 strains) sub-clades. Bars represent the standard errors.

\section{Discussion}

Alternaria is an economically important fungal genus able to colonise a wide range of crops, including cereals, fruits and vegetables [44]. Severe Alternaria infections cause both economic losses for producers and health risk for consumers, due to the accumulation of 
toxic metabolites in agri-food products [45]. Several Alternaria species, such as A. solani, $A$. alternata, $A$. arborescens, and $A$. tenuissima have been reported worldwide as causal agents of important tomato diseases, as early blight or leaf spot diseases $[8,46]$. Tomato plants can be colonised by Alternaria species during the whole growth cycle, with damage to leaves, stems and fruits. In particular, at fruit growth time, environmental conditions suitable for Alternaria infections can cause severe yield losses [47-49].

For a long time, the most important concern of phytopathogenic Alternaria species was the yield and economic losses in pre- and post-harvest conditions. In the last years, more emphasis has been posed on the mycotoxigenic risk of Alternaria species, since several studies have shown the haemato-toxic, genotoxic, and mutagenic activities of the most important Alternaria mycotoxins: AOH, AME, and TA [41,42,45]. In addition, the investigations carried out worldwide on the mycotoxin profile at a species level have provided information widely used as a chemotaxonomic approach along the genus. Indeed, chemotaxonomy has been considered a highly useful tool to be integrated in a polyphasic approach for defining species boundaries in Alternaria [21,28,50,51]. Therefore, in the present study, a set of representative Alternaria strains, isolated from tomato plants grown in greenhouses in Lebanon, were characterized by using a polyphasic approach aimed at evaluating the genetic, chemical and pathogenic differences among Alternaria species detected on tomatoes. The phylogenetic relationship among Alternaria strains was evaluated based on the sequence analyses of four informative genes, gpd, alt-a1, calmodulin, and $\beta$-tubulin [21,24]. All Alternaria strains were genetically grouped in the recently defined Alternaria section [22], in which 35 small-spore morphological Alternaria species were all synonymised with $A$. alternata species based on phylogenetic studies [22].

Alternaria alternata was the most frequently detected species, with a frequency of around $50 \%$. Similar results were previously reported in studies carried out in other countries, such as Egypt [52], Algeria [15], and Russia [16]. However, in Russian regions, A. alternata was detected alone or in a complex with A. infectoria and A. solani, which represented $30 \%$ of the strains detected [16]. In this study, $25 \%$ of the field strains were identified as $A$. arborescens. Since these strains were isolated from leaves and stems showing Alternaria symptoms, the importance of the role of $A$. arborescens species as a cause of stem canker in tomatoes in Lebanon has been confirmed.

A group of 12 Alternaria strains (25\%), genetically very close to A. citriarbusti and A.mali reference strains, were for the first time isolated from infected tomato tissues. In the last years, genetic investigations have allowed the detection of A. mali morphospecies on different crops, including wheat $[53,54]$, and Cakile maritima, a spontaneous halophyte plant growing on Tunisian sandy coasts [55]. Surprisingly, no A. solani strain was detected in Lebanon, although this Alternaria species has been reported worldwide as the most predominant pathogen associated with solanaceous plants, such as potatoes and tomatoes $[9,10]$.

We investigated the capability of Alternaria strains isolated from leaves and stems of tomato plants to colonise fruits. Indeed, in addition to the phytopathogenic role of Alternaria species, nowadays the most important concern is the toxicological risk of Alternaria mycotoxins and their accumulation on fruits and vegetable-based products. All tested Alternaria representative strains, belonging to the three phylogenetic sub-clades, showed a great capability to colonise fruits. Pathogenicity tests carried out in this study showed that the level of aggressiveness of all Alternaria strains showed a similar degree of pathogenicity, with no significant differences between the species. However, A. alternata and $A$. arborescens species seemed more capable of infecting tomato fruits, suggesting that these two species are more prone to colonising them. Wenderoth et al. [56] showed a strict correlation between $\mathrm{AOH}$ production and the capability of $A$. alternata strains to colonise tomatoes, apples and citrus fruits, supporting the role of $\mathrm{AOH}$ as a virulence factor $[57,58]$. The results of our pathogenicity assay can corroborate this role, since all strains tested, all producing $\mathrm{AOH}$ in vitro conditions, were able to colonize tomato tissues. 
The potential capacity of Alternaria strains to produce mycotoxins has also been evaluated. Almost all strains were able to synthesise the four mycotoxins tested (TA, AME, ALT and AOH), although a great quantitative variability in their production was observed. This is due to both inter- and intra-species differences, as well as to the peculiar conditions required by each species for the optimal production. A great variability to produce mycotoxin has been observed, although almost all strains were able to produce mycotoxins. Alternariol monomethyl ether was the most dominantly produced toxin (up to $16006 \mathrm{mg} \mathrm{kg}^{-1}$ ), since all Alternaria tested strains, except a single A. alternata strain and a single $A$. arborescens strain, were able to synthetise this mycotoxin. The toxic effects of this mycotoxin could be emphasised by the occurrence of sulphate and glucoside conjugate forms that Alternaria strains were showed to produce when cultured on tomatoes [59]. Tenuazonic acid, reported as the most produced mycotoxin by Alternaria species [52,60] was produced by around $70 \%$ of the Alternaria strains, with a dramatic variability of production levels (up to $4507 \mathrm{mg} \mathrm{kg}^{-1}$ ). In addition, the co-production of TA, AME, ALT and AOH by most of the strains should be taken into account, since the toxicological risk caused by possible additive and/or synergistic effects on target organisms could be exacerbated [61]. These values are higher than those found naturally in tomatoes ( $\mathrm{mg} / \mathrm{kg} \mathrm{vs.} \mathrm{ug} / \mathrm{kg}$ ) due to both ideal conditions of temperature and humidity used, and inoculated substrate that trigger the optimal synthesis of the mycotoxins targeted. Indeed, when grown in vivo on autoclaved rice, in which no mechanical barriers occur and many of the grain defences, that are thermolabile, have been suppressed, the strains could synthesize mycotoxins, providing a sort of ontological risk evaluation.

The identification of a set of Alternaria strains, using a polyphasic approach, can provide useful knowledge on the Alternaria population affecting tomato plants in the most important Lebanese areas allocated to solanaceous crops. Alternaria alternata and $A$. arborescens were the most dominant species detected, both showing a strict association with the destructive tomato disease in Lebanon. In addition, the great capability of these strains to produce mycotoxins poses evidence of the potential toxicological risk of tomatobased products, largely consumed worldwide. Finally, these results will be functional in developing integrated strategies for disease management and breeding programs to reduce Alternaria infection on tomatoes and highlight that the mycotoxin profile of Alternaria species associated with tomato disease can greatly vary according with geographical areas, likely due to the continuous changes of environmental conditions.

\section{Materials and Methods}

\subsection{Tomato Sampling and Fungal Isolation}

Samples of leaves and stems showing characteristic symptoms of early blight were collected during the 2017 crop season from tomato plants, grown under greenhouses, in the four most important Lebanese tomato producing areas: Metn (6 samples), Jbeil (48 samples), North District (26 samples), and Chouf (11 samples). After a surface-disinfection with $2 \%$ sodium hypochlorite solution for $2 \mathrm{~min}, 70 \%$ ethanol for $30 \mathrm{~s}$, and two washings with sterile distilled water for $1 \mathrm{~min}$, portions of tomato plant shoots were dried on sterile filter paper in a laminar flow cabinet. Small pieces $(2 \times 2 \mathrm{~mm})$ were then placed on potato dextrose agar (PDA, Laboratorios Conda S.A., Madrid, Spain) amended with $0.10 \mathrm{~g} \mathrm{~L}^{-1}$ streptomycin sulphate salt and $0.05 \mathrm{~g} \mathrm{~L}^{-1}$ neomycin. Petri dishes were incubated for 5 days at $25 \pm 1{ }^{\circ} \mathrm{C}$ under an alternating light/darkness cycle of a $12 \mathrm{~h}$ photoperiod. Alternaria colonies originating from tomato tissues were selected to obtain mono-conidial cultures [62]. A set of 49 representative Alternaria strains (Metn: 3 strains; Jbeil: 24 strains; North District: 15 strains; Chouf: 7 strains), together with one outgroup Stemphylium strain (ALT-1357) were selected for phylogenetic and mycotoxin profile analyses.

\subsection{DNA Extraction}

Genomic DNA was extracted and purified, according to Murray and Thompson [63], from two-day-old colonies grown at $25 \pm 1{ }^{\circ} \mathrm{C}$ on cellophane disks overlaid on PDA. Briefly, 
mycelium was collected by scraping the cellophane, powdered under liquid nitrogen and added with $600 \mu \mathrm{L}$ of CTAB buffer (100 mM Tris-Cl, pH 8.0; $1.4 \mathrm{M} \mathrm{NaCl} ; 20 \mathrm{mM}$ EDTA, $\mathrm{pH} 8.0 ; 2 \%$ cetyldimethylethylammonium bromide $(w / v) ; 0.2 \% \beta$-mercaptoethanol $(v / v))$. The samples were frozen and de-frozen three times using liquid nitrogen and a water bath at $75{ }^{\circ} \mathrm{C}$, and then incubated at $75{ }^{\circ} \mathrm{C}$ for $1 \mathrm{~h}$. Following the use of 1 volume chloroform, the clear supernatant was transferred to a new tube and precipitated with 2 volumes of isopropanol at $-80^{\circ} \mathrm{C}$ per $30 \mathrm{~min}$. The samples were then centrifuged at $14,000 \mathrm{rpm}$ for $15 \mathrm{~min}$, and the nucleic acid pellet was washed with cold $70 \%$ ethanol stored at $-20^{\circ} \mathrm{C}$, airdried, and dissolved in TE (10 mM Tris-Cl; 1 mM EDTA, pH 8). The suspension was then added with $0.1 \mu \mathrm{g} \mathrm{L}^{-1}$ DNase-free pancreatic RNase (Sigma-Aldrich, Milan, Italy) and incubated for $2 \mathrm{~h}$ at $37^{\circ} \mathrm{C}$, precipitated by the addition of 0.6 volume of $5 \mathrm{M}$ ammonium acetate and 2 volumes of cold absolute ethanol. The final DNA pellet, washed with $70 \%$ ethanol and air-dried, was dissolved in nuclease free water and stored at $-80{ }^{\circ} \mathrm{C}$ until use. Quantity and integrity of DNA were checked with Thermo-Scientific Nanodrop (LabX, Midland, ON, Canada), and on $0.8 \%$ agarose gel, by electrophoretic separation, using a standard 1 kb DNA Ladder (Invitrogen, Thermo Fisher Scientific, Carlsbad, CA, USA).

\subsection{PCR Amplification}

For each Alternaria strain, four informative target genes, allergen alt 1a (alt-a1), glyceraldeyde-3-phosphate dehydrogenase (gpd), calmodulin (calm), and $\beta$-tubulin (tub), were amplified with the primer pairs alt-for/alt-rev [64], gpd1/gpd2 [65], CALDF1/CALDR1 [24], and T1/T2 [66,67], respectively.

Amplification of alt-a1 gene was performed using a Takara (Takara Bio Inc., Otsu, Shiga, Japan) kit in mixture with $1 \times$ Takara PCR Buffer, $0.075 \mu \mathrm{L}$ of Hot Master Taq DNA Polymerase $(1 \mathrm{U} / \mu \mathrm{L}), 0.3 \mu \mathrm{L}$ of dNTPs $(10 \mathrm{mM}), 0.45 \mu \mathrm{M}$ of each primer and $15 \mathrm{ng}$ of DNA template. Amplification of gpd genes was performed using GoTaq G2 Colorless Master Mix (Promega Corporation, Madison, WI, USA) in mixture with a final concentration of $1 \times$ ready Master Mix, $2 \mathrm{mM} \mathrm{MgCl} 2,0.4 \mu \mathrm{M}$ of each primer, and $25 \mathrm{ng}$ of DNA template. Calmodulin and tub genes were amplified using $50 \mathrm{ng}$ of DNA template, $0.45 \mu \mathrm{L}$ of each primer $(10 \mathrm{mM}), 0.3 \mu \mathrm{L}$ of dNTPs $(10 \mathrm{mM})$, and $0.075 \mu \mathrm{L}$ of Hot Master Taq DNA Polymerase ( $1 \mathrm{U} / \mu \mathrm{L} ; 5$ Prime).

Amplifications were carried out in the GeneAmp PCR System 9700 thermal cycler (Applied Biosystems, Foster City, CA, USA). The PCR reactions for alt-a1, gpd, and tub were carried out by using thermal cycler parameters reported by Somma et al. [21]. To amplify the calm gene, thermal cycler parameters were: initial denaturation for 4 min at $95^{\circ} \mathrm{C}$ followed by 35 cycles of $95^{\circ} \mathrm{C}$ for $30 \mathrm{~s}, 58.5^{\circ} \mathrm{C}$ for $30 \mathrm{~s}, 72^{\circ} \mathrm{C}$ for $60 \mathrm{~s}$, and a final extension for $5 \mathrm{~min}$ at $72{ }^{\circ} \mathrm{C}$. For each reaction, a no-template control was included to ascertain the absence of contamination. The PCR products, stained with GelRed ${ }^{\circledR}\left(\right.$ GelRed $^{\circledR}$ Nucleic Acid Gel Stain, 10,000X, Biotium Inc., Fremont, CA, USA) were visualised with UV after electrophoretic separation in $1 \times$ TAE buffer, on $1.5 \%$ agarose gel and sized by comparison with 100 bp DNA Ladder (Invitrogen, Thermo Fisher Scientific, Carlsbad, CA, US).

\subsection{Sequencing and Phylogenetic Analysis}

Each PCR product was purified with the enzymatic mixture Exo/FastAP (Exonuclease I, FastAP thermosensitive alkaline phosphatase, Thermo Fisher Scientific, Vilnius, Lithuania) and then sequenced with a Big Dye Terminator Cycle Sequencing Ready Reaction Kit (Applied Biosystems, Foster City, CA, USA), according to the manufacturer's recommendations for both strands of each gene. The fragments were purified by filtration through Sephadex G-50 (5\%) (Sigma-Aldrich, Saint Louis, MO, USA) and sequenced in an "ABI PRISM 3730 Genetic Analyzer" (Applied Biosystems, Foster City, CA, USA). Partial sequences were assembled using the BioNumerics v. 5.1 software (Applied Maths, Inc., Austin, TX, USA). A phylogenetic tree of concatenated gene sequences was generated by using maximum a likelihood statistical method and bootstrap analysis (1000 replicates, removing gaps) with MEGA7 [68]. 
Gene sequences of the reference strains A. alternata E.G.S.34.016, A. tenuissima E.G.S.34.015, A. arborescens E.G.S.39.128, A. brassicicola ATCC96836, A. capsici BMP0180, A. carthami BMP1963, A. citriarbusti BMP2343, A. crassa BMP0172, A. limoniasperae BMP2335, A. longipes BMP0313, A. macrospora BMP1949, A. mali BMP3064, A. solani BMP0185, A. tagetica BMP0179, A. tangelonis BMP2327, A tomotophila BMP2032, and A. turkisafria BMP3436 were downloaded from the National Center for Biotechnology Information (NCBI) and "Alternaria Genomes Database" (AGD) and included in the phylogenetic analysis.

Sequences derived in this study were deposited in the GenBank database (Supplemental Table S1).

\subsection{Mycotoxin Production and Analysis}

Thirty-five Alternaria strains selected as representative of the population were inoculated, using three small plugs from 1-week-old colonies, on $30 \mathrm{~g}$ of autoclaved rice with $40 \%$ moisture in $250 \mathrm{~mL}$ of flasks [69]. Flasks were incubated for 21 days at $25{ }^{\circ} \mathrm{C}$ in darkness, and then the samples were finely ground with an Oster Classic grinder (220-240 V, 50/60 Hz, 600 W; Madrid, Spain).

The method used for mycotoxin extraction was based on that described by Rubert et al. [70], with some modifications. Briefly, $5 \mathrm{~g}$ of each ground sample was transferred into a $50 \mathrm{~mL}$ plastic tube containing $25 \mathrm{~mL}$ of methanol. The extraction was carried out using an Ultra Ika T18 basic Ultra-turrax, Ika, (Staufen, Germany), for $3 \mathrm{~min}$ at $1000 \mathrm{rpm}$. The extract was centrifuged at $4000 \times \mathrm{rpm}$ for $5 \mathrm{~min}$ at $5{ }^{\circ} \mathrm{C}$. One millilitre of the supernatant was filtered through a $0.22 \mu \mathrm{m}$ nylon filter and diluted before injection into high performance liquid chromatography associated with a diode array detector (LC-DAD). Tenuazonic acid, AME and AOH standards were provided by SIGMA Chemical Company (St. Louis, MO, USA). Altenuene standard was provided by ChemCruz (Dallas, TX, USA). The method used for mycotoxin analysis was based on that described by Myresiotis et al. [71], with some modifications. Tenuazonic acid, AME, ALT and TA were determined using Merk HPLC with a LC-DAD L-7455 (Merk, Darmstadt, Germany) at $256 \mathrm{~nm}$ and a Hitachi Software Model D-7000 version 4.0 ((Merck KGaA, Darmstadt, Germania) was used for data analysis. A Gemini C18 column (Phenomenex, Torrance, CA, USA) $4.6 \times 150 \mathrm{~mm}, 3 \mu \mathrm{m}$ particle size was used as the stationary phase. The mobile phase consisted of two eluents, namely eluent A (water with $50 \mu \mathrm{L} / \mathrm{L}$ trifluoroacetic acid) and eluent B (acetonitrile with $50 \mu \mathrm{L} / \mathrm{L}$ trifluoroacetic acid). A gradient program with a constant flow rate of $1 \mathrm{~mL} / \mathrm{min}$ was used, starting with $90 \% \mathrm{~A}$ and $10 \% \mathrm{~B}$, reaching 50\% B after $15 \mathrm{~min}$ and $100 \% \mathrm{~B}$ after $20 \mathrm{~min}$. Then, $100 \%$ B was maintained for $1 \mathrm{~min}$. Thereafter, the gradient was returned to $10 \% \mathrm{~B}$ in $1 \mathrm{~min}$ and allowed to equilibrate for $3 \mathrm{~min}$ before the next analysis [71].

This analytical method was validated by calculating, for each mycotoxin analysed, linearity, recovery, repeatability, reproducibility, limits of detection (LOD), limits of quantification (LOQ), and matrix effect. Linearity was evaluated using paired matrix calibrations in triplicate at concentrations between 5 and $500 \mu \mathrm{g} \mathrm{kg}^{-1}$. All of the mycotoxins showed good linearity in the working range, with resolution determination coefficients $\left(R^{2}\right)$ greater than 0.9922. LODs and LOQs were calculated by analysing blank samples enriched with the standard mycotoxins. These two parameters were assessed as the lowest concentration of the evaluated mycotoxins that gave a chromatographic peak at a signal-to-noise ratio (S/N) of 3 and 10 for LOD and LOQ, respectively. The recovery value was carried out in triplicate for three consecutive days using three addition levels: LOQ, $2 \times$ LOQ, and $10 \times$ LOQ. To calculate the matrix effect (ME), the calibration slope from the matrix calibration curve was divided by the slope of the standard calibration curve and multiplied by 100 . All of these results are shown in Table 2.

In particular, LOD and LOQ of the method used were of 0.01 and $0.1 \mathrm{mg} \mathrm{kg}^{-1}$, respectively. 
Table 2. Analytical parameters calculated for each mycotoxin tested.

\begin{tabular}{ccccc}
\hline Mycotoxin & LOD (mg/kg) & LOQ (mg/kg) & Recovery (\%) & ME (\%) \\
\hline AOH & 0.01 & 0.1 & 71 & 79 \\
AME & 0.01 & 0.1 & 70 & 78 \\
ALT & 0.01 & 0.1 & 62 & 75 \\
TA & 0.01 & 0.1 & 65 & 73 \\
\hline
\end{tabular}

\subsection{Pathogenicity Test}

The pathogenicity test for a set of 10 previously identified isolates, selected as representative of the phylogenetic groups, was carried out on six-week-old plants of 'Grappe Randala' tomato cultivar grown in the experimental greenhouse of the agricultural research station of the Holy Spirit University of Kaslik, located in Hboub, Jbeil. In detail, a conidial suspension was prepared for each isolate by gently scrapping the surface of a 10-day-old culture grown on PDA using a bacteriological loop after adding sterile distilled water containing Tween $20(0.05 \%)$, and then filtered on glass fibre and diluted to a final concentration of $10^{6}$ spores $\mathrm{mL}^{-1}$. For each isolate, 10 fruits growing on two plants were inoculated by placing $2 \mu \mathrm{L}$ of the suspension on an injury artificially made by the tip of a sterile blade. A negative control was conducted by inoculating 10 fruits with sterile distilled water containing Tween $20(0.05 \%)$. The pathogenicity of the isolates was determined by measuring the diameter of the observed lesions each three to four days for a period of two weeks.

Supplementary Materials: The following are available online at https: / www.mdpi.com/article / 10.3390/toxins13080513/s1, Table S1: GenBank accession numbers of Alternaria strain sequences obtained in the present study.

Author Contributions: Conceptualisation, W.H., M.M. and A.M.; data curation, W.H., M.M. and R.E.G.; formal analysis, W.H., M.M., R.E.G., E.G., A.S. and J.M.Q.; funding acquisition, A.F.L.; investigation, W.H., M.M., R.E.G., E.G., A.S., G.M., J.M.Q. and A.M.; methodology, W.H., M.M., A.S. and G.M.; project administration, A.F.L. and A.M.; supervision, A.M.; validation, W.H., M.M., A.S. and G.M.; visualisation, W.H., M.M. and A.M.; writing—original draft, W.H., M.M., R.E.G., A.S., G.M. and A.M.; writing-review \& editing, W.H., M.M., A.S., A.F.L. and A.M. All authors have read and agreed to the published version of the manuscript.

Funding: This research received no external funding.

Institutional Review Board Statement: Not applicable.

Informed Consent Statement: Not applicable.

Data Availability Statement: The data presented in this study are available in "Habib, W.; Masiello, M.; El Ghorayeb, R.; Gerges, E.; Susca, A.; Meca, G.; Quiles, J.M.; Logrieco, A.F.; Moretti, A. Mycotoxin Profile and Phylogeny of Pathogenic Alternaria Species Isolated from Symptomatic Tomato Plants in Lebanon. Toxins 2021, 13, 513. https:/ / doi.org/10.3390/toxins13080513".

Conflicts of Interest: The authors declare no conflict of interest.

\section{References}

1. Food and Agriculture Organization Statistics Division (FAOSTAT). Available online: www.fao.org/faostat (accessed on 13 June 2021).

2. Prusky, D.; Eshel, D.; Kobiler, I.; Yakoby, N.; Beno-Moualem, D.; Ackerman, M.; Zuthji, Y.; Ben Arie, R. Postharvest chlorine treatments for the control of the persimmon black spot disease caused by Alternaria alternata. Postharvest Biol. Technol. 2001, 22, 271-277. [CrossRef]

3. Smith, J.E.; Mengesha, B.; Tang, H.; Mengiste, T.; Bluhm, B.H. Resistance to Botrytis cinerea in Solanum lycopersicoides involves widespread transcriptional reprogramming. BMC Genom. 2014, 15, 1-18. [CrossRef] [PubMed]

4. Derbalah, A.; Shenashen, M.; Hamza, A.; Mohamed, A.; El Safty, S. Antifungal activity of fabricated mesoporous silica nanoparticles against early blight of tomato. Egypt. J. Basic Appl. Sci. 2018, 5, 145-150. [CrossRef] 
5. Logrieco, A.F.; Moretti, A.; Solfrizzo, M. Alternaria toxins and plant diseases: An overview of origin, occurrence and risks. World Mycotoxin J. 2009, 2, 129-140. [CrossRef]

6. Mamgain, A.; Roychowdhury, R.; Tah, J. Alternaria pathogenicity and its strategic controls. Res. J. Biol. 2013, 1, 1-9.

7. Rotem, J. The Genus Alternaria: Biology, Epidemiology and Pathogenicity; APS Press: St. Paul, MN, USA, 1994.

8. Pegg, G.S.; Giblin, F.R.; McTaggart, A.; Guymer, G.P.; Taylor, H.; Ireland, K.; Shivas, R.G.; Perry, S. Puccinia psidiiin Queensland, Australia: Disease symptoms, distribution and impact. Plant Pathol. 2013, 63, 1005-1021. [CrossRef]

9. Chaerani, R.; Voorrips, R.E. Tomato early blight (Alternaria solani): The pathogen, genetics, and breeding for resistance. J. Gen. Plant Pathol. 2006, 72, 335-347. [CrossRef]

10. Stammler, G.; Bohme, F.; Philippi, J.; Miessner, S.; Tegge, V. Pathogenicity of Alternaria species on potatoes and tomatoes. Fourteenth Euroblight Workshop PPO Spec. Rep. 2014, 16, 85-96.

11. Caldas, E.; Jones, A.D.; Ward, B.; Winter, C.K.; Gilchrist, D.G. Structural characterization of three new AAL toxins produced by Alternaria alternata f. sp. lycopersici. J. Agric. Food Chem. 1994, 42, 327-333. [CrossRef]

12. Soleimani, M.; Esmailzadeh, M.; Rouhani, H. Exogenous Applications of Salicylic Acid for Inducing Systemic Acquired Resistance Against Tomato Stem Canker Disease. J. Biol. Sci. 2008, 8, 1039-1044. [CrossRef]

13. Somma, S.; Pose, G.; Pardo, A.; Mulè, G.; Pinto, V.F.; Moretti, A.; Logrieco, A.F. AFLP variability, toxin production, and pathogenicity of Alternaria species from Argentinean tomato fruits and puree. Int. J. Food Microbiol. 2011, 145, 414-419. [CrossRef] [PubMed]

14. Rodrigues, T.; Berbee, M.; Simmons, E.; Cardoso, C.; Reis, A.; Maffia, L.; Mizubuti, E. First report of Alternaria tomatophila and A. grandis causing early blight on tomato and potato in Brazil. New Dis. Rep. 2010, 22, 28. [CrossRef]

15. Bessadat, N.; Berruyer, R.; Hamon, B.; Kihal, M.; Henni, D.E.; Simoneau, P.; Bataille-Simoneau, N.; Benichou, S. Alternaria species associated with early blight epidemics on tomato and other Solanaceae crops in northwestern Algeria. Eur. J. Plant Pathol. 2016, 148, 181-197. [CrossRef]

16. Kokaeva, L.Y.; Belosokhov, A.F.; Doeva, L.Y.; Skolotneva, E.S.; Elansky, S.N. Distribution of Alternaria species on blighted potato and tomato leaves in Russia. J. Plant Dis. Prot. 2017, 125, 1-8. [CrossRef]

17. Turkensteen, J.; Spoelder, J.; Mulder, A. Will the real Alternaria stand up please-Experiences with Alternaria-like diseases on potatoes during the 2009 season in the Netherlands. In PPO-Special Report no. 14. DLO Foundation; Schepers, H.T.A.M., Ed.; DLO Foundation: Wageningen, The Netherlands, 2010; pp. 165-170.

18. Simmons, E.G. Alternaria taxonomy: Current status, viewpoint, challenge. In Alternaria Biology, Plant Diseases and Metabolites; Chelkowski, J., Visconti, A., Eds.; Elsevier Science Publishers: Amsterdam, The Netherlands, 1992; pp. 1-35.

19. Simmons, E.G. Alternaria: An. Identification Manual; CBS Fungal Biodiversity Centre: Utrecht, The Netherlands, 2007.

20. Lawrence, D.P.; Rotondo, F.; Gannibal, P.B. Biodiversity and taxonomy of the pleomorphic genus Alternaria. Mycol. Prog. 2015, 15, 1-22. [CrossRef]

21. Somma, S.; Amatulli, M.T.; Masiello, M.; Moretti, A.; Logrieco, A.F. Alternaria species associated to wheat black point identified through a multilocus sequence approach. Int. J. Food Microbiol. 2019, 293, 34-43. [CrossRef]

22. Woudenberg, J.; Seidl, M.F.; Groenewald, J.; de Vries, M.; Stielow, J.; Thomma, B.; Crous, P. Alternaria section Alternaria: Species, formae speciales or pathotypes? Stud. Mycol. 2015, 82, 1-21. [CrossRef] [PubMed]

23. Lawrence, D.P.; Gannibal, P.B.; Dugan, F.M.; Pryor, B.M. Characterization of Alternaria isolates from the infectoria species-group and a new taxon from Arrhenatherum, Pseudoalternaria arrhenatheria sp. nov. Mycol. Prog. 2013, 13, 257-276. [CrossRef]

24. Lawrence, D.P.; Gannibal, P.; Peever, T.L.; Pryor, B.M. The sections of Alternaria: Formalizing species-group concepts. Mycologia 2013, 105, 530-546. [CrossRef]

25. Lawrence, D.P.; Park, M.S.; Pryor, B.M. Nimbya and Embellisia revisited, with nov. comb for Alternaria celosiae and A. perpunctulata. Mycol. Prog. 2011, 11, 799-815. [CrossRef]

26. Woudenberg, J.H.C.; Groenewald, J.Z.; Binder, M.; Crous, P.W. Alternaria redefined. Stud. Mycol. 2013, 75, 171-212. [CrossRef]

27. Al Ghafri, A.; Maharachchikumbura, S.S.N.; Hyde, K.D.; Al-Saady, N.A.; Al-Sadi, A.M. A new section and a new species of Alternaria encountered from Oman. Phytotaxa 2019, 405, 279-289. [CrossRef]

28. Patriarca, A.; Cabral, L.D.C.; Pavicich, M.A.; Nielsen, K.F.; Andersen, B. Secondary metabolite profiles of small-spored Alternaria support the new phylogenetic organization of the genus. Int. J. Food Microbiol. 2019, 291, 135-143. [CrossRef]

29. Hasan, H.A.H. Alternaria toxins in black rot lesion of tomato fruit: Conditions and regulation of their production. Mycopathologia 1995, 130, 171-177. [CrossRef]

30. Pitt, J.I.; Hocking, A.D. Fungi and Food Spoilage, 2nd ed.; Blackie Academic and Professional: London, UK, 1997.

31. Van de Perre, E.; Deschuyffeleer, N.; Jacxsens, L.; Vekeman, F.; Van Der Hauwaert, W.; Asam, S.; Rychlik, M.; Devlieghere, F.; De Meulenaer, B. Screening of moulds and mycotoxins in tomatoes, bell peppers, onions, soft red fruits and derived tomato products. Food Control 2014, 37, 165-170. [CrossRef]

32. Rosenzweig, C.I.A.; Yang, X.; Epstein, P.R.; Chivian, E. Climate change and extreme weather events: Implications for food production, plant diseases and pests. Glob. Chang. Hum. Health 2001, 2, 90-104. [CrossRef]

33. Magan, N.; Medina-Vaya, A.; Aldred, D. Possible climate-change effects on mycotoxin contamination of food crops pre- and postharvest. Plant Pathol. 2011, 60, 150-163. [CrossRef] 
34. Wang, W.; Jones, C.; Ciacci-Zanella, J.; Holt, T.; Gilchrist, D.G.; Dickman, M.B. Fumonisins and Alternaria alternata lycopersici toxins: Sphinganine analog mycotoxinsinduce apoptosis in monkey kidney cells. Proc. Natl. Acad. Sci. USA 1996, 93, $3461-3465$. [CrossRef] [PubMed]

35. Thomma, B.P.H.J. Alternaria spp.: From general saprophyte to specific parasite. Mol. Plant. Pathol. 2003, 4, 225-236. [CrossRef] [PubMed]

36. Andersen, B.; Frisvad, J. Natural Occurrence of Fungi and Fungal Metabolites in Moldy Tomatoes. J. Agric. Food Chem. 2004, 52, 7507-7513. [CrossRef] [PubMed]

37. Logrieco, A.; Bottalico, A.; Mulè, G.; Moretti, A.; Perrone, G. Epidemiology of Toxigenic Fungi and Their Associated Mycotoxins for Some Mediterranean Crops; Springer: Dordrecht, The Netherlands, 2003; pp. 645-667. [CrossRef]

38. Yamagishi, D.; Akamatsu, H.; Otani, H.; Kodama, M. Pathological evaluation of host-specific AAL-toxins and fumonisin mycotoxins produced by Alternaria and Fusarium species. J. Gen. Plant. Pathol. 2006, 72, 323-327. [CrossRef]

39. Yekeler, H.; Bitmiş, K.; Ozçelik, N.; Doymaz, M.Z.; Çalta, M. Analysis of Toxic Effects of Alternaria Toxins on Esophagus of Mice by Light and Electron Microscopy. Toxicol. Pathol. 2001, 29, 492-497. [CrossRef] [PubMed]

40. Asam, S.; Habler, K.; Rychlik, M. Determination of tenuazonic acid in human urine by means of a stable isotope dilution assay. Anal. Bioanal. Chem. 2013, 405, 4149-4158. [CrossRef]

41. Ostrý, V. Alternaria mycotoxins: An overview of chemical characterization, producers, toxicity, analysis and occurrence in foodstuffs. World Mycotoxin J. 2008, 1, 175-188. [CrossRef]

42. Solhaug, A.; Wisbech, C.; Christoffersen, T.E.; Hult, L.; Lea, T.; Eriksen, G.S.; Holme, J.A. The mycotoxin alternariol induces DNA damage and modify macrophage phenotype and inflammatory responses. Toxicol. Lett. 2015, 239, 9-21. [CrossRef]

43. Huybrechts, I.; De Ruyck, K.; De Saeger, S.; De Boevre, M. Uniting large-scale databeses to unravel the impact of chronic multimycotoxins exposures on colorectal cancer incidence in Europe. In Proceedings of the 2nd MycoKey International Conference, Wuhan, China, 16-18 September 2018; China Agricultural Science and Technology Press: Beijing, China, 2018; pp. 181-183.

44. Patriarca, A. Alternaria in food products. Curr. Opin. Food Sci. 2016, 11, 1-9. [CrossRef]

45. Cabral, L.D.C.; Terminiello, L.; Pinto, V.F.; Nielsen, K.F.; Patriarca, A. Natural occurrence of mycotoxins and toxigenic capacity of Alternaria strains from mouldy peppers. Int. J. Food Microbiol. 2016, 236, 155-160. [CrossRef] [PubMed]

46. Laemmlen, F. Alternaria Diseases. University of California Cooperative Extension Farm Advisor, Santa Barbara and San Luis Obispo Counties. 2001. Available online: https:/ / anrcatalog.ucanr.edu/pdf/8040.pdf. (accessed on 15 October 2019).

47. Nash, A.F.; Gardner, R.G. Tomato early blight resistance in a breeding line derived from Lycopersicon hirsutum PI 126445. Plant Dis. 1988, 72, 206-209. [CrossRef]

48. Hassanein, N.; Zeid, M.; Youssef, K.; Mahmoud, D. Control of tomato early blight and wilt using aqueous extract of neem leaves. Phytopathol. Mediterr. 2010, 49, 143-151.

49. Singh, H.K.; Srivastava, S.; Singh, R.B.; Singh, A.K. Management of Alternaria blight of rapeseed-mustard. J. Plant Dis. Prot. 2013, 8, 131-136.

50. Andersen, B.; Sørensen, J.L.; Nielsen, K.F.; Ende, B.G.V.D.; De Hoog, S. A polyphasic approach to the taxonomy of the Alternaria infectoria species-group. Fungal Genet. Biol. 2009, 46, 642-656. [CrossRef] [PubMed]

51. Zwickel, T.; Kahl, S.M.; Rychlik, M.; Müller, M.E.H. Chemotaxonomy of Mycotoxigenic Small-Spored Alternaria Fungi-Do Multitoxin Mixtures Act as an Indicator for Species Differentiation? Front. Microbiol. 2018, 9, 1368. [CrossRef] [PubMed]

52. El Gobashy, S.F.; Mikhail, W.; Ismail, A.M.; Zekry, A.; Moretti, A.; Susca, A.; Soliman, A.S. Phylogenetic, toxigenic and virulence profiles of Alternaria species causing leaf blight of tomato in Egypt. Mycol. Prog. 2018, 17, 1269-1282. [CrossRef]

53. Ramires, F.A.; Masiello, M.; Somma, S.; Villani, A.; Susca, A.; Logrieco, A.F.; Luz, C.; Meca, G.; Moretti, A. Phylogeny and Mycotoxin Characterization of Alternaria Species Isolated from Wheat Grown in Tuscany, Italy. Toxins 2018, 10, 472. [CrossRef]

54. Masiello, M.; Somma, S.; Susca, A.; Ghionna, V.; Logrieco, A.F.; Franzoni, M.; Ravaglia, S.; Meca, G.; Moretti, A. Molecular Identification and Mycotoxin Production by Alternaria Species Occurring on Durum Wheat, Showing Black Point Symptoms. Toxins 2020, 12, 275. [CrossRef]

55. Chalbi, A.; Sghaier-Hammami, B.; Meca, G.; Quiles, J.M.; Abdelly, C.; Marangi, C.; Logrieco, A.F.; Moretti, A.; Masiello, M. Characterization of mycotoxigenic Alternaria species isolated from the Tunisian halophyte Cakile maritima. Phytopathol. Mediterr. 2020, 59, 107-118. [CrossRef]

56. Wenderoth, M.; Garganese, F.; Schmidt-Heydt, M.; Soukup, S.T.; Ippolito, A.; Sanzani, S.M.; Fischer, R. Alternariol as virulence and colonization factor of Alternaria alternata during plant infection. Mol. Microbiol. 2019, 112, 131-146. [CrossRef]

57. Graf, E.; Schmidt-Heydt, M.; Geisen, R. HOG MAP kinase regulation of alternariol biosynthesis in Alternaria alternata is important for substrate colonization. Int. J. Food Microbiol. 2012, 157, 353-359. [CrossRef]

58. Wojciechowska, E.; Weinert, C.; Egert, B.; Trierweiler, B.; Schmidt-Heydt, M.; Horneburg, B.; Graeff-Hönninger, S.; Kulling, S.E.; Geisen, R. Chlorogenic acid, a metabolite identified by untargeted metabolome analysis in resistant tomatoes, inhibits the colonization by Alternaria alternata by inhibiting alternariol biosynthesis. Eur. J. Plant Pathol. 2014, 139, 735-747. [CrossRef]

59. Soukup, S.T.; Kohn, B.N.; Pfeiffer, E.; Geisen, R.; Metzler, M.; Bunzel, M.; Kulling, S.E. Sulfoglucosides as Novel Modified Forms of the Mycotoxins Alternariol and Alternariol Monomethyl Ether. J. Agric. Food Chem. 2016, 64, 8892-8901. [CrossRef]

60. Garganese, F.; Schena, L.; Siciliano, I.; Prigigallo, M.I.; Spadaro, D.; De Grassi, A.; Ippolito, A.; Sanzani, S.M. Characterization of Citrus-Associated Alternaria Species in Mediterranean Areas. PLoS ONE 2016, 11, e0163255. [CrossRef] 
61. Crudo, F.; Varga, E.; Aichinger, G.; Galaverna, G.; Marko, D.; Dall'Asta, C.; Dellafiora, L. Co-Occurrence and Combinatory Effects of Alternaria Mycotoxins and other Xenobiotics of Food Origin: Current Scenario and Future Perspectives. Toxins 2019, 11, 640. [CrossRef] [PubMed]

62. Simmons, E.G.; Roberts, R. Alternaria themes and variations (73). Mycotaxon 1993, 48, 109-140.

63. Murray, M.; Thompson, W. Rapid isolation of high molecular weight plant DNA. Nucleic Acids Res. 1980, 8, 4321-4326. [CrossRef] [PubMed]

64. Hong, S.G.; Cramer, R.A.; Lawrence, C.B.; Pryor, B.M. Alt a 1 allergen homologs from Alternaria and related taxa: Analysis of phylogenetic content and secondary structure. Fungal Genet. Biol. 2005, 42, 119-129. [CrossRef] [PubMed]

65. Berbee, M.L.; Pirseyedi, M.; Hubbard, S. Cochliobolus phylogenetics and the origin of known, highly virulent pathogens, inferred from ITS and glyceraldehyde-3-phosphate dehydrogenase gene sequences. Mycologia 1999, 91, 964-977. [CrossRef]

66. Glass, N.L.; Donaldson, G.C. Development of primer sets designed for use with the PCR to amplify conserved genes from filamentous ascomycetes. Appl. Environ. Microbiol. 1995, 61, 1323-1330. [CrossRef]

67. O'Donnell, K.; Cigelnik, E. Two divergent intragenomic rDNA ITS2 types within a monophyletic lineage of the fungus Fusarium are nonorthologous. Mol. Phylogenet. Evol. 1997, 7, 103-116. [CrossRef]

68. Kumar, S.; Stecher, G.; Tamura, K. MEGA7: Molecular Evolutionary Genetics Analysis Version 7.0 for Bigger Datasets. Mol. Biol. Evol. 2016, 33, 1870-1874. [CrossRef]

69. Li, F.-Q.; Yoshizawa, T.; Kawamura, O.; Luo, X.-Y.; Li, Y.-W. Aflatoxins and Fumonisins in Corn from the High-Incidence Area for Human Hepatocellular Carcinoma in Guangxi, China. J. Agric. Food Chem. 2001, 49, 4122-4126. [CrossRef]

70. Rubert, J.; Dzuman, Z.; Vaclavikova, M.; Zachariasova, M.; Soler, C.; Hajslova, J. Analysis of mycotoxins in barley using ultra high liquid chromatography high resolution mass spectrometry: Comparison of efficiency and efficacy of different extraction procedures. Talanta 2012, 99, 712-719. [CrossRef] [PubMed]

71. Myresiotis, C.K.; Testempasis, S.; Vryzas, Z.; Karaoglanidis, G.S.; Papadopoulou-Mourkidou, E. Determination of mycotoxins in pomegranate fruits and juices using a QuEChERS-based method. Food Chem. 2015, 182, 81-88. [CrossRef] [PubMed] 